\title{
ANTHROPOGENIC DISTURBANCES ON THE REGENERATION OF TREE SPECIES IN THE MIXED BROADLEAVED FOREST OF THE HIMALAYAN REGION, NEPAL
}

\section{A. Giri ${ }^{1}$ and K. Katzensteiner ${ }^{2}$}

\section{ABSTRACT}

The aim of this study was to assess the anthropogenic impacts on the vegetation structure and regeneration of dominant tree species in the community managed mixed broadleaved forests of the Sargamatha (Everest) National Park buffer zone area. The forest plots were categorized into disturbed and semi-disturbed considering the scale of anthropogenic disturbances such as percentage of biomass extraction, lopping, tramping coverage and grazing intensity. For each forest type, three radii $(10 \mathrm{~m}, 5 \mathrm{~m}$ and $2.5 \mathrm{~m})$ plots were laid for sampling trees, sapling and seedling layers, respectively. In both the forest sites, Quercus semecarpifolia and Rhododendron arboreum were the main dominant tree species. The distribution of $Q$. semecarpifolia and $R$. arboreum along with diameter classes showed high stem density mainly concentrated in 2-15 $\mathrm{cm}$ diameter class. In both sites, the density of $R$. arboreum showed increment from sapling to seedling stage, while no seedling of $Q$. semecarpifolia was recorded in the disturbed site. The absence of $Q$. semecarpifolia seedlings in the disturbed forest sites could be associated with the practice of biomass removal and forest management activities. The study attributed that $R$ hododendron species in the study sites were not frequently cut, browsed, or lopped due to their religious belief and its ornamental value. Thus $R$. arboreum is expected to be slowly expanded if biotic pressure is maintained less. This may cause change in the vegetation structure and scarcity of resources for livelihood. On the whole, managing the forest in an equitable and sustainable way could satisfy basic needs and improve the livelihood of rural people in the study area.

Key words: mixed broadleaved forest, anthropogenic impacts, vegetation, bufferzone INTRODUCTION

In Nepal, forests are one of the most important livelihood options. Before 1957, villagers were responsible for forest management to meet the local demands of fuel wood, fodder, litter and grazing. The management system was especially based on indigenous practices of protection and utilization of resources (Acharya 2002). Later in 1957, Government of Nepal introduced the Forest Nationalization Act which includes all forests (even landlord owned forest) under the ownership of the government. The result increased deforestation rate in the country especially in the midhill regions. During the late 1970s', a community forest management program was launched with the concept of mitigating deforestation and forest degradation in the midhill regions. Community forestry (CF) is defined as a process through which government transfers responsibilities of managing forests to communities (Kanel 2004). Later, a high deforestation rate in the high mountain was recorded due to over-utilization because of cold and slow vegeta- 
tion growth. To prevent from further degradation, a community forestry program was launched in the Himalaya region during the 1980's (Karky and Skutsch 2009). Since then many high mountain forests near to human settlements have been handed over to the community for the management. A total of 1,350,655 ha of national forest have been handed over to 15,256 community forest user groups in the country. In which, 244,255 ha of high mountain forest are under community forest management program with 2,638 community forest user groups (Community Forest Division, Department of Forest, Nepal, Jan. 21, 2011). Recently, the community forestry is regarded as a most successful forest management programme in terms of resource management and supply of forest products (fodder, fuel wood, timber, litter, etc.) to the rural communities. But on the other hand, due to lack of proper forest management skills among communities, the community forest in various parts of the country is degrading and developing into the mono-dominant forest. Some example can be illustrated as; a mixed Shorea robusta forest developed to a mono-dominant S. robusta forest (Shrestha 2005, Acharya et al. 2007), mixed Castanopsis tribuloides and Quercus glauca forest was converted into C. tribuloides and Q. glauca forests (Baral and Katzensteiner 2009). Based on the above background, the study was undertaken in the mixed broadleaved community forest of the Sagarmatha National Park buffer zone area to study the effect of anthropogenic disturbances and community management activities on the forest structure and regeneration of the dominant plant species.

\section{STUDY AREA}

This study was conducted on April to September 2010 in Chaurikharka VDC of the buffer zone area of the Sagarmatha National Park and located between $27^{\circ} 42^{\prime} 09^{\prime \prime}-27^{\circ} 46^{\prime} 23^{\prime \prime} \mathrm{N}$ and $86^{\circ} 42^{\prime} 51-86^{\circ} 43^{\prime} 28^{\prime \prime} E$. The elevation of the study area ranged between $2800-3000 \mathrm{~m}$. Red Panda Community Forest (RPCF) is situated in this VDC and covers an area of 300 ha. RPCF has a mixed broadleaved forest dominated by Rhododendron arboreum and Quercus semecarpifolia as overstorey. Other co-dominant species are Eurya acuminata, Ilex dyperina, Lyonia ovalifolia and Sorbus cuspidata. Agriculture and animal husbandry are important livelihood options of the study area. So the forest in the study areas are extensively used for extracting fodder, litter, firewood, and non-timber forest products. The climate of the study site is determined by monsoon. The mean daily minimum temperature of the coldest month was $-0.1^{\circ} \mathrm{C}$. Mean daily temperature of the warmest month was $18.2^{\circ} \mathrm{C}$ (mean of 2004-2008). The mean annual precipitation (Chaurikharka station: latitude $27^{\circ} 41^{\prime} 48^{\prime \prime} \mathrm{N}$, longitude $86^{\circ} 43^{\prime} 17^{\prime \prime}$ E, Altitude 2660) was $2076 \mathrm{~mm}$, a mean of 38 years (1970-2008).

\section{MATERIALS AND METHODS}

\section{Land use classification}

The gradient of forest disturbances were used for the assessment of vegetation structure and regeneration of dominant plant species. Forest plots were categorized as disturbed and semi-disturbed by visually inspecting the site condition and field measurement data on litter raking, percentage of lopped trees, grazing intensity, trail and trampling coverage. If these parameters fall below $30 \%$, a plot was considered as semi-disturbed and more was considered as disturbed forest plots. 


\section{Experimental design}

A transect survey was carried out across the study area to collect the primary information of disturbed and semi-disturbed forest sites. Nine forest plots were placed in the first transect in the lower mid slope (disturbed site), whereas 8 forest plots were in the upper mid-slope (semi-disturbed) of the mixed broadleaved forest. Forest plots were laid down considering the same vegetation types, site condition and topography. The sampling was done with the help of 3 nested circular plots for vegetation (trees, saplings and seedlings). Trees with $<5 \mathrm{~cm} \mathrm{DBH}$ and $>1.3 \mathrm{~m}$ height were measured within the circle of radius $2.5 \mathrm{~m}$; trees with $5-10 \mathrm{~cm} \mathrm{DBH}$ and height $>1.3 \mathrm{~m}$ were measured within the circle of radius $5 \mathrm{~m}$; and trees $>10 \mathrm{~cm} \mathrm{DBH}$ and height $>1.3 \mathrm{~cm}$ were measured within the circle of $10 \mathrm{~m}$ radius plots, respectively. Similarly, to obtain the data on the regeneration status of dominant trees, seedlings less than $1 \mathrm{~m}$ in height was counted in the circular plots of radius $2.5 \mathrm{~m}$.

\section{Analytical method}

\section{Basal area}

Basal area of individual tree $\left(\mathrm{m}^{2}\right)=(\mathrm{DBH} / 2)^{2} \pi$

Where, $\mathrm{DBH}$ is the diameter at breast height $(\mathrm{cm}), \pi=3.14$

\section{Density}

Density of a species (individual ha-1) number of individual of that species $=X 10000$ area sampled

\section{RESULTS AND DISCUSSION}

\section{Vegetation structure}

Quercus semecarpifolia and Rhododendron arboreum are the main dominant tree species of the mixed broadleaved forest. In the disturbed sites, the total density of trees (>10 cm DBH) was $576 \pm 97$ stems ha $^{-1}$, in which $Q$. semecarpifolia and $R$. arboreum shared $52 \%$ and $28 \%$ of the total density respectively. The total basal area of trees $(>10 \mathrm{~cm} \mathrm{DBH})$ was $31 \pm 6.5 \mathrm{~m}^{2} \mathrm{ha}^{-1}$. Overall, the biggest share of basal area at disturbed site was contributed by $Q$. semecarpifolia $(66 \%)$ alone, while $R$. arboreum had the smallest share $(22 \%)$. Similarly in the semi-disturbed

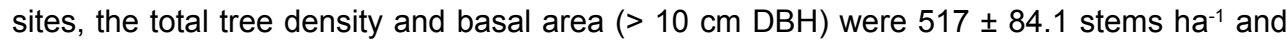
$20.4 \pm 3.1 \mathrm{~m}^{2} \mathrm{ha}^{-1}$, respectively. The highest density was recorded for $Q$. semecarpifolia $(50 \%)$ followed by $R$. arboreum (11\%). The basal area was also higher for $Q$. semecarpifolia (65\%) than $R$. arboreum (7\%). Overall, the density and basal area was almost similar for Q. semecarpifolia in both the forest sites, while for $R$. arboreum the density and basal area decreased from disturbed to semi disturbed forest sites (table 1). 
Table 1. Density (stems $\mathrm{ha}^{-1}$ ) and Basal Area (BA, $\left.\mathrm{m}^{2} \mathrm{ha}^{-1}\right)$ of trees $(>10 \mathrm{~cm} \mathrm{dbh})$ in disturbed and semi-disturbed forests of mixed broad leaved forest (mean $\pm S D$ ).

\begin{tabular}{|l|l|l|l|l|l|}
\hline & \multicolumn{1}{|c|}{ Family } & \multicolumn{2}{l}{ Disturbed forest } & \multicolumn{2}{l|}{$\begin{array}{l}\text { Semi-disturbed } \\
\text { forest }\end{array}$} \\
\hline & & Density & BA & Density & BA \\
\hline Quercus semecarpifolia Sm. & Fagaceae & 300 & 20.45 & 254 & 13.49 \\
\hline Rhododendron arboreum Roxb. & Ericaceae & 159 & 7.71 & 59 & 1.39 \\
\hline Eurya acuminata DC & Theaceae & 39 & 0.66 & 8 & 0.08 \\
\hline Pinus wallichiana A.B. Jacks & Pinaceae & 17 & 0.53 & 16 & 0.8 \\
\hline $\begin{array}{l}\text { Litsea doshia (Buch.-Ham. ex D. } \\
\text { Don) Kosterm }\end{array}$ & Lauraceae & 17 & 0.41 & 23.89 & 0.63 \\
\hline Ilex dipyrena Wall. & & & & & \\
\hline Lyonia ovalifolia (Wall.) Drude & Equifoliaceae & 14 & 0.52 & 4 & 0.03 \\
\hline Tsuga dumosa (D. Don) Eichler & Pinaceae & 7 & 0.24 & 47 & 2.33 \\
\hline Viburnum erubescens Wall. ex DC & Sambucaceae & 7 & 0.15 & 43 & 0.69 \\
\hline Sorbus cuspidata (Spach) Hedlund & Rosaceae & 7 & 0.22 & - & - \\
\hline $\begin{array}{l}\text { Magnolia campbellii Hook. f. \& } \\
\text { Thomson }\end{array}$ & Magnoliaceae & - & - & 39 & 0.72 \\
\hline Rhododendron spp. & & 7 & 0.14 & 12 & 0.12 \\
\hline Taxus wallichiana Zucc. & Ericaceae & - & - & 8 & 0.08 \\
\hline Total & Taxaceae & - & - & 4 & 0.05 \\
\hline & & $576 \pm 97$ & $31.0 \pm 6$ & $517 \pm 84$ & $20.4 \pm 3$ \\
\hline
\end{tabular}

\section{Regeneration pattern}

Saplings

The total sapling density was three times lower in the disturbed site ( $481 \pm 59$ saplings ha $\left.^{-1}\right)$ than in the semi-disturbed site (1242 \pm 168 saplings ha- $\left.^{-1}\right)$. In disturbed site, $Q$. semecapifolia had 156 saplings ha-1 followed by $R$. arboreum ( 141 saplings ha-1). The sapling to tree ratio was almost similar $(0.9: 1)$ for the both species (Q. semecarpifolia and $R$. arboreum). In semidisturbed forest, $R$. arboreum had the highest sapling density (477 saplings ha-1), which is six times higher than that of $Q$. semecarpifolia (79 saplings ha-1) (table 2). The sapling to tree ratio for $R$. arboreum had the highest ratio of 8: 1 while $Q$. semecarpifolia had 1:1 (table 3 ).

Seedlings

In disturbed forest sites, total seedling density was $1642 \pm 488$ seedlings ha-1 in which $R$. arboreum shared the highest seedling density $(65 \%)$ and no seedlings of $Q$. semecarpiflolia were recorded. The seedling to tree ratio was 7:1 for $R$. arboreum. In the semi-disturbed forest, the total seedling density was $3963 \pm 368$ seedling ha-1, in which the contribution of $R$. arboreum had $30 \%$ and Q. semecarpifolia had $18 \%$ (table 2). The seedling to tree ratio was also higher 
for $R$. arboreum (20:1) and lower for $Q$. semecarpifolia (3:1). While comparing both forest sites, the seedling density of $R$. arboreum is higher in the disturbed forest sites and it decreased in semi-disturbed forest sites. The result showed opposite trend for $Q$. semecarpifolia with the increment of seedling density in semi-disturbed sites than disturbed sites (table 3 ).

Table 2. Density (stems ha-1) of tree saplings $(2-5 \mathrm{~cm} \mathrm{dbh}$ and $>1.3 \mathrm{~m}$ height) and seedlings $(<1 \mathrm{~m})$ in disturbed and semi-disturbed mixed broadleaved forest (mean \pm SD).

\section{Species}

\begin{tabular}{|l|l|l|l|l|}
\cline { 2 - 5 } & Disturbed & $\begin{array}{l}\text { Semi-dis- } \\
\text { turbed }\end{array}$ & Disturbed & $\begin{array}{l}\text { S e m i - d i s - } \\
\text { turbed }\end{array}$ \\
\hline Quercus semecarpifolia Sm. & 155.7 & 79.6 & NA & 735.4 \\
\hline Rhododendron arboreum Roxb. & 141.5 & 477.7 & 1075.7 & 1188.9 \\
\hline $\begin{array}{l}\text { Litsea doshia (Buch.-Ham. ex D. } \\
\text { Don) Kosterm. }\end{array}$ & 84.9 & 31.8 & 452.9 & 113.2 \\
\hline Lyonia ovalifolia (Wall.) Drude & 42.4 & 127.4 & NA & 113.2 \\
\hline Ilex dipyrena Wall. & 14.1 & 31.8 & NA & 56.6 \\
\hline $\begin{array}{l}\text { Sorbus cuspidata (Spach) Hed- } \\
\text { lund }\end{array}$ & 14.1 & & NA & 113.2 \\
\hline $\begin{array}{l}\text { Magnolia campbellii Hook. f. \& } \\
\text { Thomson }\end{array}$ & - & 159.2 & 113.2 & 509.5 \\
\hline Others & 28.3 & 334.4 & NA & 1132 \\
\hline Total & $481.2 \pm 59$ & $\begin{array}{l}1242 \\
168\end{array}$ & $1641.9 \pm 488$ & $3963.2 \pm 368$ \\
\hline
\end{tabular}

Table 3. Sapling/seedling to tree ratio in disturbed and semi-disturbed mixed broadleaved forest.

Species

Sapling to tree ratio

\begin{tabular}{|l|l|l|l|}
\hline Disturbed & $\begin{array}{l}\text { Semi-dis- } \\
\text { turbed }\end{array}$ & Disturbed & $\begin{array}{l}\text { Semi-dis- } \\
\text { turbed }\end{array}$ \\
\hline 0.9 & 1 & $*$ & 3 \\
\hline 0.9 & 8 & 7 & 20 \\
\hline 5 & 1 & 25 & 5 \\
\hline 6 & 11 & $*$ & 9.5 \\
\hline
\end{tabular}




\section{Population structure}

The density-diameter distribution of $R$. arboreum displayed inverse J-shaped, while the distribution was not continuous for Q. semecarpifolia in both forest sites (fig.1 and 2). Pertaining to the population structure of $Q$. semecarpifolia, the distribution at both forest sites is more or less similar demonstrating a pattern that more individuals belong to smaller diameter classes $(<20 \mathrm{~cm} \mathrm{DBH})$.

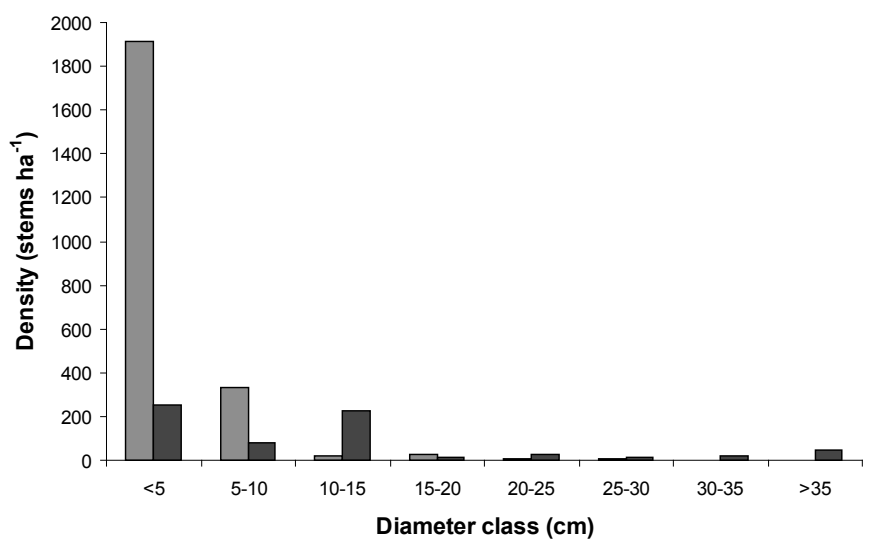

$\square$ Rhododendron arboreum $\square$ Quercus semecarpifolia

Figure 1. Density-diameter distribution of the dominant tree species in a series of 5 cm diameter class (semi-disturbed forest).

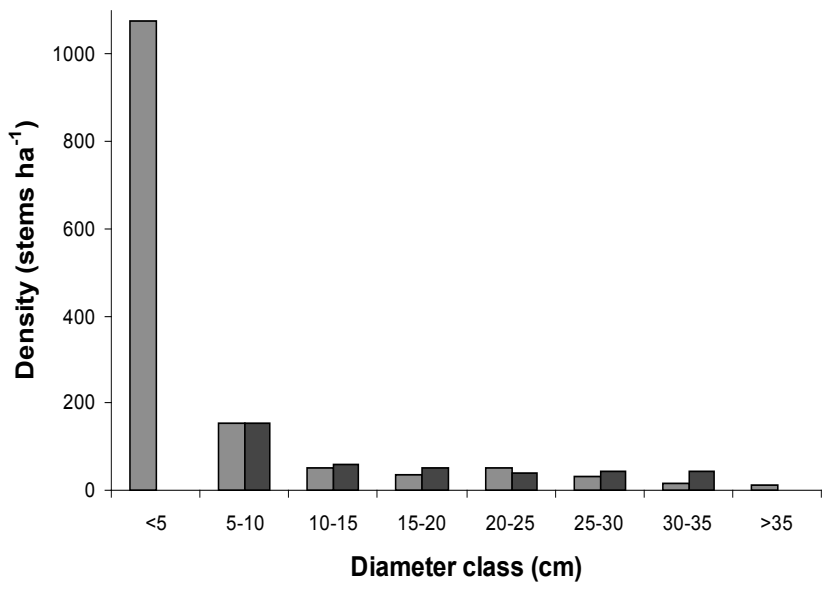

$\square$ Rhododendron arboreum $\square$ Quercus semecarpifolia

Figure 2. Density-diameter distribution of the dominant tree species in a series of 5 cm diameter class (disturbed forest). 


\section{Forest structure}

The total density and basal area of tree species was lower in the semi-disturbed forest than in the disturbed forest sites. The lower value of tree density and basal area indicated that two sites are at different developmental stages. Similarly, the density of trees in both sites is lower than reported for similar forest types from central and eastern Nepal (Yoda 1968, Inges and Vetaas 2007) and India (Singh et al. 1994, Adhikari et al. 1995). Overall, the presence of higher density of young trees $(<20 \mathrm{~cm} \mathrm{DBH})$ and lower basal area in both the sites suggested that the forest was disturbed in the past and is in the regeneration stage. The visual observation of the larger sized cut stumps present in the study sites also justifies the result.

\section{Disturbance and regeneration}

The oak forest is one of the oldest vegetation types in the Himalaya (Shrestha and Paudel 1996). The green twigs of Quercus semecarpifolia are used as dry season fodder especially at high altitudes over $2000 \mathrm{~m}$ (Jackson 1987). Similarly, Q. semecarpifolia is the preferred species for fuelwood and litter. The litter is one of the good sources of fertilizer (Subedi 1998). As a result, massive lopping of this plant has been found at the disturbed forest site. In general, the practice of biomass harvesting from the forest is continue unless there is no change in the traditional farming systems.

The density diameter distribution of $Q$. semecarpifolia in disturbed sites showed a consistent decrease from sapling to seedling stage, while in semi-disturbed sites the trend was opposite i.e a slight increment in seedling stage. Similarly, Rhododendron arboreum showed an increment from sapling to seedling stage. The reason is that $R$. arboreum are not frequently cut, browsed or lopped due to religious belief, ornamental value and management activities. The result indicated that if the same scale of disturbances continues it might lead to the development of a mono-dominant $R$. arboreum forest in the near future. Similar results have been obtained from a community forest of Central Nepal (Shrestha 2005, Acharya et al. 2007, Baral and Katzensteiner 2009). Species preference, management activities, overutilization and removal of other species from a mixed forest stand can lead to a monoculture in the forest (Shrestha et al. 2010).

Higher proportion of smaller diameter individuals in both the forest sites could be due to severe disturbance in the past. Similar result was obtained by Vetaas (2000) from Himalayan region of Nepal and Khan et al. (1987) from Meghalaya (India). There are various factors (Light, moisture, temperature) responsible for the regeneration of plants. The effect of selective thinning of trees increased light intensity, soil temperature and seedling recruitment (Sapkota 2009). But in contrast, heavy lopping of trees for foliage causes a decrease in ground litter, seed production, creates mechanical obstruction for seed germination and seedling establishment (Kumar et al. 1994). Additionally, forage collection and forest grazing also have negative impacts on regeneration. In line with this, the negative impact of forest grazing in the regeneration of $Q$. semecarpifolia was observed in Bhutan (Tashi 2004).

The high anthropogenic interference especially heavy lopping of trees for fodder reduces the rate of seed production. Seeds of $Q$. semecarpifolia even germinate in the tree under warm and humid environment (Negi and Naithani 1995). The seed desiccates fast when there is lack 
of favorable moisture condition after reaching the ground. A short period of seed viability and anthropogenic disturbances such as litter raking, grazing and trampling create dry microsites which could be one of the causes limiting its regeneration in the disturbed forest sites. Moreover, looping of $Q$. semecarpifolia reduces litter production of this species and indirectly favors litter inputs from Rhododendron spp. to the forest floor. The increase in the litter of Rhododendron spp. causes an alternation in the $\mathrm{N}$-cycle in the forest via the formation of polyphenol-organic $\mathrm{N}$ complexes (Wurzburger and Hendrick 2007). This contributes to the suppression of hardwood seedlings. The observation made by various ecologists (Nilsen et al. 1999, Nilsen et al. 2001) also confirmed that conifer and hardwood regeneration was suppressed by Rhododendron maximum and changed the forest composition.

Any species that dominates a particular community today may be replaced by other tree species if there is lack of regeneration. In connection with this, tree regeneration was lower in disturbed sites than semi-disturbed sites. Similarly, the sapling/seedling to tree ratio of $Q$. semecarpifolia was also low in the disturbed forest sites. The increase of seedling and sapling densities in the semi-disturbed forests provide evidences that low biotic interference has a positive effect for regeneration of plants whereas high biotic pressures have detrimental effects for population structure and regeneration of plant species. The view was also strengthened by various ecologists (Glatzel 1999, Walter et al. 2002, Inger and Vetaas 2007).

Furthermore, the results indicate that it could be possible that the combined effects of anthropogenic disturbances and inherent behaviour of seed has hampered the regeneration of Q. semecarpifolia in the disturbed site of the mixed broadleaved forest. Moreover, livestock grazing, browsing and trampling could be also a reason. The decrease in the population of tree seedlings in the anthropogenically disturbed sites of high montane forests of the Garwal Himalaya (India) was reported by Sundriyal and Bisht (1988). If the present disturbance continues, it is likely that $R$. arboreum coverage slowly expands and will dominate the area. There may be a scarcity of $Q$. semecarpifolia in the near future where the entire communities are dependent on this species for livelihood.

\section{ACKNOWLEDGEMENTS}

We are grateful to Himalaya and Red Panda community forest user groups (Chepplung and Monjo) for the permission to conduct the research activities. We are indebted to the local people of Chepplung and Monjo for proving necessary information during the field work.

\section{REFERENCES}

Acharya, K.P., 2002. Twenty-four years of community forestry in Nepal. International Forestry Review 4(2):149-156.

Acharya, K.P., K.R. Gautam, B.K. Acharya and G. Gautam, 2007. Participatory assessment of biodiversity conservation in community forestry in Nepal. Banko Janakari, 16:6-56.

Adhikari, B.S., Y.S. Rawat and S.P. Singh, 1995. Structure and function of high altitude forests of central Himalaya I. Dry matter dynamics. Annals of Botany, 75:237-248. 
disturbance gradient in a central mid-hill community forest of Nepal. Banko Janakari, 19(1):3-10.

Glatzel, G., 1999. Historic forest use and its possible implication to recently accelerated tree growth in central Europe. In Karjalainen, T., H. Spieker and O. Laroussine (eds) Causes and Consequences of Accelerated Tree Growth in Europe. European Forest Institute (EFI) Proceedings No 27. Joensuu, Finland pp 65-74.

Inger, E.M. and O.R. Vetaas, 2007. Does regulated land use allow regeneration of keystone forest species in the Annapurna Conservation Area, Central Himalaya? Mountain Research and Development, 27(4):345-351.

Jackson, J.K., 1987. Manual of Afforestration in Nepal. Department of forest, Kathmandu 402 p.

Kanel, K.R., 2004. Twenty-five years pf community forestry: contribution to millennium development goals. In Kanel, K.S., P. Mathama, B. R. Kanel, D. R. Niaurla, A. R. Sharma and M. Gautam (eds) Proceeding of the fourth workshop on community forestry, Community Forestry Division, Department of forest, Kathmandu, Nepal.

Karky, B.S. and M. Skutsch, 2009. The cost of carbon abatement through community forest management in Nepal Himalaya, Ecological Economics, doi:10.1016/j.ecolecon.Accessed on 2009.10.04.

Khan, M., J.P.N. Rai and R.S. Tripathi, 1987. Population structure of some tree species in disturbed and protected sub tropical forests of northeast India. Acta Ecol., 8:247-255.

Kumar, R., A.K. Singh and S.G. Abbas, 1994. Range in population structure of some dominant tree species of dry Peninsular Sal forest. Indian Forester, 120:343-347.

Negi, S.S. and H.B. Naithani, 1995. Oaks of India, Nepal and Bhutan. Dehradun: International Book Distributors, India.

Nilsen, E.T., J.F. Walker, O.K. Miller, S.W. Semones, T.T. Lei and B.D. Clinton, 1999. Inhibition of seedling survival under Rhododendron maximum (Ericaceae): could allelopathy be a cause? American Journal of Botany, 86:1597-605.

Nilsen, E.T., B.D. Clinton, T.T. Lei, O.K. Miller, S.W. Semones and J.F. Walker, 2001. Does Rhododendron maximum L. (Ericaceae) reduce the availability of resources above and belowground for canopy tree seedlings? American Midland Naturalist, 145:325-343.

Sapkota, I.P., 2009. Species diversity, regeneration and early growth of Sal forests in Nepal. Responses to Inherent disturbances regimes. PhD thesis. Swedish University of Agricultural Sciences, Alnarp.

Shrestha, B.B., 2005. Fuelwod harvest, management and regeneration of two community forests in central Nepal. Him. J. Sci., 3:75-80.

Shrestha, R.K. and K.C. Paudel, 1996. Oak forest under threat: an urgent concern for the mountain environment biodiversity: in context of south Asia. Ecological Society (ECOS), 
Kathmandu, pp 114-119.

Shrestha, U.B., B.B. Shrestha and S. Shrestha, 2010. Biodiversity conservation in community forests of Nepal: rhetoric and reality. International Journal of Biodiversity and Conservation, 2(5):98-104.

Singh, S.P., B.S. Adhikari and D.B. Zobel, 1994. Biomass, productivity, leaf longevity and forest structure in the central Himalaya. Ecological Monographs, 64(4):401-421.

Subedi, M.N. 1998. Some functional expression on diameter distribution, density and basal area of oak (Quercus semecarpifolia Sm) forest in Nepal Himalaya. J. Phytogeogr. and Taxon, 46:65-70.

Sundriyal, R.C. and N.S. Bisht, 1988. Tree structure, regeneration and survival of seedlings and sprouts in high Montane forest of the Garwal Himalayas, India. Vegetatio, 75:87-90.

Tashi, S., 2004. Regeneration of Quercus semecarpifolia Sm. in an old growth oak forest under Gidakom forest management unit, Bhutan. MSc. Thesis, Wageningen University and Research Centre, Wageningen, The Netherlands.

Vetaas, O.R., 2000. The effects of environmental factors on regeneration of Quercus semecarpifolia Sm. in central Himalaya, Nepal. Plant Ecol., 146:137-144.

Walter R., G. Grazer and K.Wangdi, 2002. Cattle grazing in the Conifer forests of Bhutan. Mountain Research and Development, 22(4):368-374.

Wurzburger, N. and R.L. Hendrick, 2007. Rhododendron thickets alter N-cycling and soil extracellular enzyme activities in southern Appalachian hardwood forests. Pedobiologia, 50:563-576.

Yoda, K. 1968. A preliminary survey of the forest vegetation of eastern Nepal III. Plant biomass in the sample plots chosen from different vegetation zones. Journal of the College of Arts and Sciences, Chiba University, 5(1):99-140.

\section{AUTHOR'S ADDRESS}

Anjana Giri'

Nepal Academy of Science and Technology (NAST), Khumaltar, Lalitpur, Nepal (email: anjanagiri73@gmail.com)

\section{Klaus Katzensteiner ${ }^{2}$}

Institute of Forest Ecology, University of Natural Resources and Life Science, Vienna, Austria 